\title{
RELIGIOUS TRENDS OF THE MUGHAL AGE
}

\section{(Late) Dr. Riaz ul Islam*}

Survey of the Preceding Age: Islam had reached the sub-continent long before the advent of Muslim political power. Even in this early pre-political phase, Islam had had important repercussion on Indian thought and life. No less an authority, Dr. Tara Chand ascribes the unityism of Sankracharya to the influence of Islam. With the establishment of Muslim political power, Muslim religious thought and activity began to assume a more elaborate, articulate and organized shape. The religious classes viz, the Ulama and the Mashaikh played a very important role in the spreading of Muslim culture and faith in Indo-Pakistan in the pre-Mughal period. The Ulema, the doctors of Muslim Law, represented the orthodox aspect of the faith. They were well versed in the Islamic lore and gave an authoritative interpretation of the doctrines and percepts of Islam. They underlined the importance of tradition and discipline in religious matters. It was, however, the Mashaikh, the Mystics who played the leading role in the propagation of Islamic ideas. Humble in address, speaking the dialect of the people, they spread far and wide and by their preaching, their noble bearing and sympathetic approach they won respect for their faith. There was much that appeared to be common to Sufism and Hindu mysticism. The dhikr of the Sufis resembled the japna of the Hindu yogis, the pir and the guru occupied almost identical places in their respective systems. Even the spiritual contents of the two systems had something in common. Thus started, almost unnoticed, a slow and silent among the mystic orders was the Chishtia Silisila. From Khwaja Moinuddin Ajmeri (Died 1236) to Sheikh Nizamuddin (1238-1325) there is an unbroken succession of great mystics, who set up a very high level of idealism in their profession and practice. They kept aloof from Kings and courts but mixed with the people, and when Sheikh Nasiruddin asked in permission of Sheikh Nizamuddin Aulia to leave Delhi and lead a secluded life, the preceptor remarked "you must remain Delhi and suffer the company of men." A certain amount of strain between the Ulema and the Mashaikh was always there. Sheikh Qutbuddin Bakhtiar Kaki Qazi, Hamiduddin Nagauri and Sheikh Nizamuddin Anbia were accused of anti-shariah practices by the orthodox ecclesiastics of their times. The great mystics generally laid emphasis on the observance of the Shariat but the bolder spirits among their followers sometimes transgressed the bounds of religious propriety. A number of such mystic zealots were executed during the reign of Firoz Shah. One of these had claimed divinity.

*Professor Emirates, Department of History, University of Karachi 
Jhss, Vol. 1, No.1 , January to June 2010

\section{BHAKTI MOVEMENT}

An interesting product of the interaction between Islam and Hinduism was the Bhakti cult. It was an attempt from the Hindu side to incorporate such of the elements of Islam, especially of the Islamic mysticism, into Hindu faith as were easily assimilable. The Bhakti cult taught devotion to a personal God. It helped mitigate caste distinctions. It laid emphasis on fervor and devotion as against forms and dogmas of religion, and considered the various religions as different paths to a common goal. The Bhakti hymns breathed the spirit of Persian Sufis poetry. The dsohas of Kabir (1440-50) and the writings of Nanak (1469-1530) re-echo the strains of the lyrics of Hafiz and Jami.

\section{MAHDAVIST MOVEMENT}

The sixteenth century was an age of religious ferment. With the first millennium of Islam in sight, it was also an era of expectation and religious tension. The tension set into motion forces which worked in several directions. One product of this tension and the feeling of expectation was the Mahdavist Movement. Mulla Mohammad of Jounpur, who proclaimed himself Mahdi in 1495 at Mekkah was a man of different stamp than the many other Mahdis of history. He was a man of extraordinary intelligence and scholarship. His life was throughout marked by piety and nobility. Unlike the other Mahdis, he never aspired for political power. On two occasions, when his disciples offered him armed assistance to overcome his enemies, he spurned their offer and remarked "wield the sword on your inordinate desires. The helper of Mahdi is God."

"His success was primarily due to his sincerity and fervor, the purity of his character and the selflessness, whose personality had a chastening and purifying influence on their lives...... Robbers and bandits would leave their profession and adopt dhikr and contemplation and would dedicate their lives to God. He breathed a spirit of love and amity among his contemporaries....It was the honesty and integrity, the resignation and unworldliness of Syed Mohammad which appealed to his audience, and secured converts to his way of thought." (vide Mahdari movement in India by Dr. S.N Rizvi, Medieval India Quarterly, Aligarh, 1950).

The orthodox looked upon Syed Mohammad as a religious and political rebel. The Syed himself claimed for his teaching complete conformity with Islam. He laid great emphasis on the other0worldly aspect of religion. $\mathrm{He}$ taught renunciation of the world. Dhikr, which meant the performance of prayers in a state of utter absorption in God, was the foremost duty, and all that which interfered with the practice of dhikr, eg, the quest of knowledge or the earning of livelihood was unlawful (vide, Medieval India Quarterly, Aligarh, 1950). The Mahdi enjoined on his followers to withdraw themselves from society and to live in Daeras (worship circles). They were 
not to depend on charity and gifts, nor were they to busy themselves with earning wealth. Accumulation of wealth was indeed proscribed. Private and public service were similarly proscribed as they entailed dependence on others. "Whatever was obtained by joint effort was distributed equally among all the members of the Daera.....Nobody was allowed to receive more than his share." The Mahdi's own son and daughter-in-law were not allowed anything beyond their due share. Nobody was allowed to store anything for further use. The Mahdavis went about fearing the advent of the resurrection every moment.

After Syed Mohammad's death in 1505, his work was continued by his son and successor Syed Mahmud. He encouraged the establishment of various dearas, which now became the vehicle of propagation of the Mahdavi mission. The persecution and banishment of the Mahdavis led to the multiplication of the daeras and to a widespread propagation of the Mahdavi faith.

The subsequent history of Mahdavism is a chequered one. The Mahdavis professed to remain aloof from politics. But they held wealth and worldly power in contempt and considered the rulers and ruled as equals. Unlike most of the orthodox ulema of the day, they refused to observe the court etiquette. This, along with their general opposition to the orthodoxy in profession and practice and their condemnation of the ulema for their worldliness and wealth, soon brought them into conflict with the legally constituted authority. The ulema represented them to the sultans as a menace to their authority. Mulla Abdullah Sultanpuri was instrumental in inducing Islam Shah Suri to persecute the Suris. Sheikh Abdullah Niazi annoyed the Suri Sultan by greeting him with a plain Assalamo Alaik. He was therefore grievously flogged at the instigation of Mulla Abdullah..... Sheikh Alai of Bayana was another notable mahdavi who met a similar fate. On his conversion to Mahdavism, he had forsaken all his worldly riches and had become a powerful protagonist of the new faith. He had immense success as a preacher and won many adherents. He was summoned to the capital by Islam Shah but had shortly afterwards to be banished from the capital as many officials and nobles were falling under his spell and joining the new faith. He was exiled to Hindia but there the governor of the place himself fell under his charm, and so the Sheikh had to be exiled from there too. His case was referred to Sheikh Budh of Bihar who reported favorably but his recommendations were tempered with in transit by his own son with a view to please Mulla Abdullah. Subsequently, at the instigation of the Mulla, Islam Sheikh asked him to abjure his faith. On his refusal he was flogged and he died at the third stroke. This happened towards the middle of the sixteenth century.

The last in the line of the great Mahdavi preachers was Miyan Mustafa of Gujrat. The orthodox ulema of Gujrat wanted Akbar to execute him for his heterodoxy. But when he was brought before the Emperor, he was able to 
convince him of his sincerity. In the discussions and disputations that followed, he worsted his critics. Akbar showed him great favor. He died in 1575 while returning from the royal court to Gujrat.

\section{THE SHATTARI ORDER}

It was an old order which originated with Sheikh Bayazid Bustami (753845). It was brought to India by Sheikh Abdullah Shattari. Unlike other mystic saints, he lived in a princely fashion and went from place to place with his band of uniformed followers asking people to join his order. After his death at Mandu in 1485, his work was continued by his disciples, Sheikh Mohammad Ala and Sheikh Hafiz of Jaunpur. The former spread the order in Bengal, and it was the Bengal branch which produced the greatest saint of the order, Syed Mohammad Ghaus of Gawaliar. Sheikh Hasiz was also fortunate in having a line of able disciples, the most notable among them being Sheikh Buddhan who "popularized the Shattari silsila in Northern India."

Syed Mohammad Ghaus, the greatest figure of the movement, was deeply influenced by wujudy philosophy. For many years he lived a life of physical penances and austerities and spiritual ecstasy. Early in life he wrote a book entitled Jawahir-i-Khamsa, which invited the censure of the orthodox camp on account of its bold and unrestrained expression of pantheistic ideas. Later on the saint issued a revised version of the book, omitting or altering many of the objectionable passages. Another of his work, Bahr-ul-Hayat, the ocean of life, "discusses the influence of Hindu ideas on Muslim mysticism. It was indeed a percussion of Majma-ul-Bahrain of Dara Shikoh. Syed Mohammad Ghaus's knowledge of Hindu mystic thought was intimate and deep, his approach was sympathetic and unprejudiced. He had intimate relation with the Hindus. He would stabd up to welcome every Hindu visitor. His hobby was keeping bulls and cows. (2)

The attitude of the Sheikh soon brought him into conflict with the orthodoxy. During the saint's sojourn in Gujrat, he was condemned to death by Sheikh Ali Muttaqi. Sultan Mahmud referred the matter to Sheikh Wajihud-din Alavi, the leading scholar of Gujrat. He was also impressed and charmed by the personality of the saint. Not only he tore up the condemnatory fatwa of Sheikh Muttaqi but himself became an ardent admirer of the saint and lived to be one of his principal successors (khalifa). It bears an eloquent testimony to the greatness of Mohammad Ghaus that he should have made an easy conquest of a great scholar of mature ideas and long standing. The Sheikh's support of Syed Wajih-ud-din secured the saint from further attacks from the orthodox camp. The Shattari saints in India had very intimate relations with kings and Emperors and held jagirs from them. This uncommon of piety and plenty invited unfavorable comments from contemporaries and Shattarisin their defense advanced the unconvincing

plea that they mixed with the rich for the sake of the poor. Sheikh Abdullah 
Shattari and after him Sheikh Bahauddin had close personal relations with the Khilaji Sultan of Mandu and lived at his court.

Syed Mohammad Ghaus of Gawaliar established a lifelong relation with the Mughals. He actively helped Babar in the reduction of the fort of Gawaliar. $\mathrm{He}$ and his brother, Sheikh Bahlol, had great influence with Humayun. Sheikh Bahlol was highly respected and trusted by Humayun. When Hindal rebelled at Agra during Humayun's absence in Bengal, the Sheikh was entrusted by the emperor with the task of treating with the rebel prince. The mission cost him his life for the prince got him murdered. He was known for his learning and piety as well as for his riches and political influence.

After Humayun's defeat and exit from India, Syed Mohammad Ghaus very wisely left for Gujrat in order to avoid any untoward affair with Sher Shah. He lived there for about 18 years and visited Champanir, Baruch and Ahmedabad. He obtained great influence their and in Sheikh Wajihuddin he found an illustrious disciple who propagated his mission and founded a powerful branch of the silsila in Gujrat.

Ghaus remained loyal to the Mughals even in their adversity and kept himself in touch with Humayun through correspondence. Sometime after the Mughal restoration, the saint set out from Gujrat and reached Agra in 1558. Humayun's death (1556) had deprived him of an old friend and patron. The saint did not feel happy in the new dispensation. Akbar showed him due respect but his Sardar-i-jahan Sheikh Gadai did not take to him kindly. Mulla Abdul Qadir thus notes these affairs in his characteristic style: "the saint's arrival was unpleasing to Sheikh Gadai, who on account of pettiness, enmity and jealousy.... which to the saints of India is their mutual relations are the very necessaries of life, looked on his arrival as a case of opening a shop above his own shop." He pointed out to Bairam Khan certain passages in the saint's work entitled "Mirajia" in which he had described his own ascension (mi'raj) and claimed certain superiority over prophets. The powerful regent used his influence against the saint. A series of disputations and controversies took place which put the saint in a very awkward situation. He therefore retired to his jagir at Gawaliar where he passed the rest of his life. The saint remained loyal to Akbar and when the latter visited Gawaliar, he showed the young king great affection and even enrolled him among his disciples. Akbar however, did not attach any importance to it. Sometime later, Akbar utilized the good offices of the saint in bringing to submission the powerful Afghan noble, Fatah Khan. The saint died in 1563and is buried at Gawaliar. His mausoleum there is one of the most notable monuments in the city. He was like his brother a rich man and had a jagir of one crore dams at Gawaliar. Abul Fazl, in spite of his catholicity of outlook, does not speak well of the saint.

The Shattari order did not last long after the death of the saint. The movement failed as it lacked elements of popular appeal. It had a highbrow atmosphere. Its pantheistic philosophy was incomprehensible to the common 
people. ${ }^{1}$ As Mr. Khaliq Nizami has pointed out "the Shattaris neglected the common man. They fixed their gaze on palaces and mansions....the silsila identified itself so closely with the state and the rulers that its prestige waxed and waned with the attitude of the rulers.....Akbar's indifference so completely smashed the organization that it could not regain its prestige."

\section{AKBAR (1553-1603)}

Akbar was endowed with a deeply religious mind and a keenly inquisitive temperament. There is ample evidence of his religiosity and conformity in the early years of his life. He would, for example, himself recite the call to prayers and even clean the mosques. During the formative period of his life, he came under certain liberal influence which gave depth as well as breadth to his religious outlook. His regent Bairam Khan was a shia. His Persian tutor Abdul Latif was so liberal in ideas that the Shias considered him a Sunni and the Sunnis dubbed him a Shia. He taught to his royal pupil the doctrine of Sulh-i-kul or universal peace based on concept of broad toleration of various peoples and faiths. Sheikh Gadai who became his Sadrus-Sadoor or minister of Ecclesiastical Affairs in 1559 was a Shia. In 1662, Akbar freed himself from the tutelage of Bairam. He now began to work out a new policy towards the non-Muslims. The new policy was inaugurated by Akbar's marrying Raja Bihar Mal's daughter in 1562. The new imperial consort was allowed to retain her faith and was indeed provided with all the facilities to practice it in the royal palace. The two succeeding years witnessed the abolition of tax on Hindu pilgrims and of Jiziya.

These events are a clear evidence of a change in outlook, if not of a change in religious beliefs. About a decade before the advent of Sheikh Mubarak and his son at the court, Akbar had already struck out a new direction for himself. Partly this may be ascribed to the disgust which he felt at the conduct of the leaders of orthodoxy, who should in fact be largely considered responsible for the decline of the fortunes of Islam in contemporary India. Makhdum-ul-Mulk Mulla Abdullah Sultanpuri had a distinguished career as a scholar. Humayun gave him the title of Makhdumul-Mulk; Sher Shah made him Shaikh-ul-Islam. He exercised tremendous influence under Islam Shah but he misused his powers partly to enrich himself and partly to persecute those who differed from him on religious problems. When he died, he left behind immense treasures- 3 crore rupees and several boxes full of silver bricks. He persecuted the Mahdavists and their sympathizers and the Shias. One detail of his personal life would suffice to show the pattern of his religious conformity- at the end of every year he temporarily handed over his hoard of gold and silver to his wife in order to escape zakat. Abdunnabi as the Sadar-us-Sadoor had in his hands an unlimited patronage whose distribution was shamelessly dishonest and

1. Med. India Quarterly, 1951. 
corrupt. Local ecclesiastics improved upon the examples of their superiors. What is more, the orthodoxy was divided against itself. Makhdumul Mulk started a regular campaign against Abdunnabi and said that prayers could not be offered under his Imamat as he was suffering from piles. Sheikh Abdunnabi was retaliated by declaring him an ignoramus. Haji Ibrahim Sirhindi declared the wearing of yellow and red colored clothes lawful, in order to ingratiate himself with the Emperor. The chief Qazi declared the Haji's declaration heretical.

These mutual recrimination and anathematization of the ecclesiastics served to discredit the whole set of them. Their understanding of Islam was unimaginative and uninspiring. With a damnable divergence between their own profession and practice, they set up ti persecute others for alleged lapses for correct behavior. Akbar's disgust with them might have remained a negative feeling but for the arrival of Sheikh Mubarak at the psychological moment. The Sheikh had been hunted from place to place like a beast of prey by the orthodox party for hid heterodox views. What is more, in point of intellect and learning, the Sheikh and his sons were superior to their opponents and could beat them on their own ground. It is rather a controversial point whether Abul Fazl and Faizi were Muslims or heretics. The general view has been that they were responsible for Akbar's religious vagaries. A modern writer* has attempted to show that while both of them passed through a phase for skepticism, they regained faith subsequently. Faizi's tafsir of Quran is advanced as an argument in his favor. Abul Fazl was intellectually more gifted of the two and it was in fact he who supplied Akbar with most of his ideas. Akbar indeed had fully shown the trend of his mind much before Abul Fazl's advent at the court, but the latter's intellect gave Akbar's vague spiritual dissatisfaction a definite direction and shape. Possibly, Islam as presented by a section of the orthodox ulema failed to satisfy the deep spiritual cravings of both Akbar and Abul Fazal, and this brought them very closer to each other.

*S.M Ikram- Rud-i-Kauthar

\section{THE IBADAT KHANA}

Akbar's quest for truth led to the setting up of the Ibadat Khana and the debates on religion held therein. The behavior of the ulemas at these gatherings, their unseemly disputes over precedence in seating order, their mutual recrimination and their hairsplitting arguments made Akbar feel sick of them. He ordered Mulla Abdul Qadir Badayuni to turnout anyone who misbehaved, and the Mulla, who himself belonged to the orthodox school, said in an aside thaw that a host of ulema would lose their seat if the order was really enforced. The Ibadat Khana, which in the beginning admitted 
Muslims of different persuasions, was now thrown open to the representatives of all religions. The motive was obvious: Akbar was extending his quest for truth to a wider field.

\section{THE MAHDAR}

Akbar's disgust with the depressing disputes of the ulema was fully exploited by Sheikh Mubarak. He drew up a Mahdar to which signatures were affixed bu the Makhdum-ul-Mulk, Sadar-us-sadoor Abdunnabi and other ulemas. The Mahdar authorized Akbar, in case of difference of opinion among the ulemas, to select any one of the conflicting views as the correct one, and further to issue orders which should not, however, be incompatible with the Holy Quran. The Mahdar, which has been wrongly described as the decree of infallibility, has been a source of much controversy. Curiously enough the majority of Hindu writers have attempted to prove that it was based on the shariat. The consensus of the Muslim opinion, however, regards the Mahdar as a mischievous document. In Akbar's own time it was condemned by Qadi-ul-Quddat Mulla Yazdi of Jaunpur, Qadi-ul-Quddat Yaqub of Bengal, Shah Tayyab of Banaras, Shah Abdul Haq Muhaddith of Delhi and Mujaddid Alf-i-Ihani. In modern times it has been severely criticized by Maulana Abdul Kalam Azad. Maulana MAnazir Ahsan Gilani and Maulana Salman Nadvi. The main line of criticism is that Akbar was not fit to exercise the enumerated functionsin view of his ignorance of the Muslim law and of his heretical ideas, and that the decree was uncalled for as the powers enumerated were inherent in the functions of the Imam. It was "a moment of heterodoxy and heresy" and its signatories were "progenitors of mischief and slaves of the world."

\section{DIN-i-ILAHI}

Akbar studied all religions. None gave satisfaction to his wayward and curious mind- a mind which had not passed through the discipline of systematic learning. His position as the absolute ruler of a big empire was not conducive to a critical pursuit of truth; for every whim and caprice was sure to be commended by the courtiers as the stroke of a genius. It would be unfair to Akbar to question his bonafides and to double the genuine keenness of his enquiry after truth. In 1578, four years before the promulgation of Din-i-Ilahi, Akbar had a curious religious experience. He was engaged in Kamargha hunt when suddenly he had a fit of spiritual ecstasy. Te hunt was stopped and the captured animals were released. But the final issue of his religious cravings and search is far from being commendable. The Din-iIlahi is an eclectic faith with pantheistic basis, but it betrays the psychology of a puerile and immature mind. It is an ill-assorted collection of such elements, called out from various religions, as appealed to Akbar's fancy. As an experiment in religion making, it was a complete failure; hardly a score 
of men accepted it. It reflects credit on Akbar that he made no attempt to use the authority of the state to spread his religion. Only one Hindu viz; Birbal joined the Din-i-Ilahi, perhaps, because he had a sense of humor. Khan-iAzam Mirza Aziz Koka, Akbar's foster brother felt so much disgust with his vagaries that he emigrated to Mekkah. From there he wrote a letter warning him against the ulterior motives of the clique that was trying to alienate him from the Mohammadan faith (din-i-Mohammadi) and drawing his attention to the fact that no sultan had ever had the temerity of assuming the prophetic function and of abrogating the religion of Mohammad. Strangely enough Khan-i-Azam later on returned from Mekkah and accepted the Din-i-Ilahi. Another notable convert was Jani Khan, Governor of Thatta, who wrote to the Emperor that he has scornfully rejected the formal and traditional faith of Islam which had come down to him from his forefathers and that he had embraced the Din-i-Ilahi Akbar Shahi for the sake of which he was ready to sacrifice his riches, his life, his honor and his religion. The qualifying words "the formal and traditional" were evidently meant as a stop for public opinion and as a veneer behind which to take cover from the charge of apostasy.

What were the motives behind Akbar's religious policy? Was it inspired by religious motives or political considerations? Certain early measures such as the abolition of Jaziya and the pilgrimage tax were evidently inspired by a desire to broaden the basis of his political authority. But all subsequent developments such as the Ibadat Khana, the inter-religious debates, the invitation to the Jesuits, the Jain and the Zoroastrian divines, the prohibition of hunting and of meat, and the Din-i-Ilahi were the outcome of a genuine but misguided religious quest. The consideration shown to such microscopic minorities as Jains and Parsis and to the alien Christians was not the result of nau political necessity.

\section{DIN-I-ILAHI}

There is substantial evidence showing Akbar's deviation from religion. Did he, then, entirely abjure Islam? Did he consider a Muslim or not? These are controversial questions to which it is difficult to give straight and categorical answers. It is interesting to note that the Hindu writers generally try to prove that Akbar was a good Muslim. Perhaps they apply to Islam the analogy of their own religion which is elastic enough to hold in its gaunt a great variety of religious beliefs. Akbar in his letter to Abdullah Khan Uzbek asserted his firm belief in Islam and claims credit for having spread Islam to infidel territories and converting temples into mosques. He speaks of his resolve to expel Christians from their strongholds on the western coast. It is difficult to accept this letter on its face value. Akbar had written this letter to a political adversary who was well known for his extreme orthodoxy. Could Akbar have done anything but assert his own conformity? It is to be remembered 
that Akbar's religious vagaries had aroused strong resentment in certain quarters and several leading ecclesiastical had come out with open condemnation of Akbar. Some of them had put themselves in touch with Mirza Hakim and wanted him to supplant Akbar on the Mughal throne. It view of this it would have been nothing but suicidal for Akbar to write of his doubts to a foreign Muslim potentate who himself had territorial ambitions in India. As for his reference to his demolition of temples and the expulsion of Christians, it is sufficient to recall that Akbar had temples built in his own palaces and that he had himself invited Jesuit missionaries to his court and had given them permission to build churches and make converts.

Badayuni's contention is that Akbar had ceased to b Muslim. He brings against him a long list of charges, for example, he had developed a positive hatred for Islam, converted mosques into stables, forbade Muslims from prayers, fasts and pilgrimage, and so on. Fortunately, there is concluding evidence in contemporary writings to disprove these wild charges. There are only too many references to the offering of pilgrimages and prayers in the record of the same period and $\mathrm{n}$ fact, in Badayuni's own history.* Badayuni's kkegation of Akbar's persecution of Islam falls to the ground. The truth appears to be that Badayuni as deliberately misconstructed Akbar's own discontinuation of Muslim practices as general regulations forbidding these practices. If Akbar gave up fasting, Badayuni reported that Akbar banned fasting. Badayuni was indeed the past master of insinuations. He used a highly suggestive language to implicate those he wanted to censure.

Badayuni's contention that Akbar had totally rejected Islam is also incorrect. In fact, Din-i-Ilahi's central dogma is that the unity of God is taken from Islam. Even the prejudiced accounts of Jesuits bear witness to the fact that Akbar continued ot hold in high regard many Islamic institutions.

The charges that Akbar persecuted Islam and that he totally rejected stand disproved. But does this lead us to conclude that AkbarS was a Muslim? Perhaps not. Islam claims the total allegiance of man. In the matter of faith and belief it is totalitarian. One cannot accept it partially. It is unlike Christianity and Hinduism in this respect.* It is incompatible with any belief which is in any way contrary to its tenets or which directly or indirectly calls into question their absolute veracity. The reverence shown to fire and the sun, the making lawful of the flesh of bore, the marriage with Hindu ladies who were allowed to retain their faith, the permission given to the Jesuits to make converts to Christianity-------all these display a deliberate adoption of principles and practices contrary to Islam. It is also clear that these were not errors of omission or commission for which a man may feel sorry, but were

\footnotetext{
*Two examples will suffice to bring out the point. Badayuni reports the pilgrimage of Gulbadan Begum and the stopping of pilgrimage in the same year. As for prayers, Badayuni himself reports that Mir Fathullah Shirazi offered prayers in the court itself and was not interfered with. See Sri Ram Sharma: The Religious Policy of the Mughal Emperors, p.43.
} 
undertaken as desirable practices. All the above cited things are to be viewed in context of Akbar's eclecticism and his search for truths in all religions. His doings are thus not to be looked upon as the misdeeds of an erring Muslim but as the deliberate acts of a person who did not consider himself bound by Islamic law and who looked for inspiration to sources other than Islam. This was veritable apostasy. It did not necessarily involve a total rejection of Islam on the part of Akbar, but it did involve a loss of faith.

\section{ADVENT OF THE NAQSHBANDIA ORDER}

The Chihtia and the Suhrwardia silsilas had so far held the field in IndoMuslim mysticism. The Naqshbandia order was founded by Khwaja Bahauddin of Bokhara (d. 1389). From its inception, the order laid great emphasis on conformity to the Shariat. The Salik was by no means to lose sight of his moorings while voyaging in the deep waters of mysticism. The new order thus combined orthodoxy with mysticism. The sheikhs of the order (unlike the Chishti mystics) cultivated the society of the kings and the nobles in order to use their influence in reforming the people. Babar and his father were both attached to the Naqshbandia order. In India, the order was introduced and popularized by Khwaja Baqi Billa Berang (1563-1603). He came to India late in life and died within three or four years of his arrival. $\mathrm{He}$ was a man of great piety and learning. Such was the power of his mind and spirit that within this brief space of a few years he was able to lay the foundation of a powerful religious movement. His circle of disciples included a large number of Mughal nobles. Nawab Muratza Khan Sheikh Farid and Abdur rahim Khan-i-Khanan were among his notable admirers.

\section{SHEIKH AHMAD SARHINDI (1564-1624)}

Mujaddid Alf Sani was a disciple of Khwaja Baqibilla. He was a man of vast learning and extraordinary intellect and processed a great force of character. He gave a permanent stamp of his own to the Naqshbandia order. He gave it a new philosophy, which stood in direct contradistinction to the Wujudu philosophy which had held the field ever since the days of the Sheikh-iAkbar, Nuhyuddin Ibn Arabi (1161-1240). The Mujaddid rejected the theory of wahdat-ul-wujud and described it as a very low stage of mystic experience, a deception of which the Salik should disabuse his mind in his progress to higher stages of mystical experience. According to the wujudi philosophy, the material universe was just a reflection of or an emanation from God who constitutes the reality of all existence, everything besides God having an unreal appearance is the cult of "hama ust," says Ibn Arabi. "There is nothing but God, nothing in existence other than He; there is not even a there where the essence of all things is one." This bears close resemblance to, though it is not identical with, Ployinus theory of emanation. 
There was a far cry from Islam's simple doctrine of monotheism to Ibn Arabi's pantheism, yet such was the power of his intellect that he left a deep stamp on Muslim thought. Many Muslims subscribed to wahdatulwujud less the affirmation of the existence of the finite and temporal world should involve polytheism or shirk.

The Mujaddid rejected wahdatulwujud both on the basis of his own mystical experience and the teaching of the Holy Prophet. He developed his own philosophy of existence which is known as wahdatusshahud. He affirms the duality and not identity of God and the finite universe. The universe is not the reflection but the creation of God. These two approaches to the apprehension of Reality symbolize on the intellectual plain two different religious tendencies. The wujudi philosophy commended the annihilation of self and was conducive to questism and seclusion. The shuhudi conception affirmed the existence of human ego and called forth activity. Wujudi philosophy was condemned by the orthodox ulemas as un-Islamic and the more daring spirits on the wujudi camp frequently came into clash with the Shariat. The wahdatusshuhud brought mysticism and Shariat on a common point and culminated their conflict. The former had a family resemblance with Greek, Persian and Vedantic ideas and made Islam only one of the many paths leading to Reality. The latter was fundamentally based on Islam and affirmed its truth and its suspension of the earlier systems of belief. The Mujaddid bravely pitted himself against the process of approximation and rapprochement between Islam and Hinduism which had been in going on for centuries and which had culminated in the fanciful nevertheless portentous experiment of Din-i-Ilahi. India had been absorbing foreign races and religions in her amorphous religious system and Hali, the poet of our national regeneration has rightly described her as the swallower peoples (akkalul ummam). The issue which Mujaddid had to face was a historic onewas Islam to lose its identity as a religious system, was it to be one of the many paths leading to a common truth, or was it to be a missionary faith, sharply distinguished from other faiths, the only faith which had superseded other creeds? Or to put the same thing in terms of human groups, were the Muslims to lose their individuality into a lose, non-descript cosmopolitan congregation of peoples, or were they to maintain their integrity as a socioreligious community with its own pervading cultural values? Was the principal of the historical continuity of the group to be asserted and maintained, or was it to lose ground to an eclectic mysticism and universal humanism? Mujaddid Alf Sani stood unflinching for the principle of historic continuity. Taking a long view of things, he took the first substantial step towards separatism in Indo-Muslim history, the separatism which in the fullness of time culminated in the demand for the achievement of Pakistan. This is not just a literary flourish or a political propaganda; this is a view which I maintain as a serious student of history. The Mujaddid's efforts should be seen in their proper historical perspective. The next phase of the struggle thus initiated was the War of Succession, as we will presently see. 
The Mujaddid as the first sizeable leader of ideas to assert the separatist principles had naturally to over emphasize his point and to take up an extreme position. He thus maintained that the contemporary decline in the fortunes of Islam was due to the close association of Muslim kings with Hindus, that the Jaziya was meant to humiliate the non-Muslims, that the glory of Islam was lay in degrading the and that the Hindu God Rama and Krishna were despicable creatures of God. The hindus were not, however, the only target of his wrath, the non-sunni Muslim sects too came in very bitter comments. Such of the orthodox ulema who cared more for riches and palaces than for truth and piety and who acquicised in the whims of their masters and patrons were special objects of his contempt and censure. He considered them responsible for the contemporary religious disorders. The Mujaddid himself was a man of great force of character and had the courage of his convictions. When he was summoned to the court of Jahangir, he refused to prostrate himself or bow his head before the throne after the etiquette of the court. Some of his writings such as his claim to have attained a place higher than those of the pious caliphs during his mystical flights (vide from the famous Maktub Mazadhum) or that his own services to the Muslim faith had enhanced the status of the Holy Prophet, occasioned great controversy and invited censure from the ulema. It was his failure to satisfy Jahangir on the first point and his high handed deport before the throne which landed him in prison where he remained for one year.

It is the most curious incident in the history of ideas that the revivalist creed and the "orthodox mysticism" enunciated by the great Mujaddid degenerated after his death into one of the most fantastic cult ever conceived. And the irony of the whole matter lies in the fact that it were some of the isolated remains of the Mujaddid, later on explained away by him, on which the new cult of Qayyumia was built up. The Qayyum which is in fact one of the 99 attributes of God and means one who Maintains or the Great Preserver, was according to the subscribers of the cult, a sort of vicegerent of God on the earth to whom He had delegated many of his powers. Thus, it was the Qayyum who kept the world going, from whom the solar bodies and all organic and inorganic things seek their orders and without whose support the world would crash into ruin. The change of seasons and the harvest was due to him. The Mujaddid was, according to the Qayyums, the first Qayyum. He was followed by his son Khwaja Mohammad Masum, the second Qayyum. Three generations after the Mujaddid, three or four of his successors were contending for the Qayyun's office, each one claiming that the universe was revolving around his person. The sublime thus passed into the ridiculous. The successors of the Mujaddid and other such of the Naqshbandia order maintained the Mujaddid'sattitude towards non-Muslims and non-Sunnis and were responsible for a number of Shia-Sunni riots in Kashmir. 


\section{ABDUL HAQQ MUHADDITH}

Another great figure of the age was Sheikh Abdul Haqq of Delhi known as Muhaddith on account of the great contribution he made to the science of Traditions of Holy Prophet (ilm-ul-Haddith).

He was not entirely untouched by mysticism but he based his religious ideas exclusively on the Shariat and was a great bulwark of orthodoxy. $\mathrm{He}$ thus represented another wing of reaction this teacher at Mekkah, Sheikh Abdul Wahab Muttaqi, who was himself the disciple of Sheikh Ali Muttaqi. Both the Muttaqis were Indian Muslims who had successively migrated to Mekkah and had their established their reputations scholars and teachers of outstanding merit. It reflects great credit on Indo-Muslim scholarship that teachers from India earned a noble place for themselves in the land of the origin of faith. Both the aforesaid teachers were in the spiritual line Imam Ibn Taimiyya and looked askance on all deviations from the straight path of orthodoxy. To them all mystical ideas that did not fit in the framework of the shariat were heretical. They condemned the mystic system of Ibn Arabi. Sheikh Abdul Haqq was a prolific writer and left behind him a large number of books on a variety of subjects.

\section{JAHANGIR AND SHAH JAHAN}

Jahangir maintained the liberal policy of his father. He nixed with equal freedom with Muslim mystics, with Hindu Yogis and with Christian Fathers. The observance of Hindu festivals at the court was continued. He wisely avoided, however, the vagaries of his father. Though religion does not seem to be the inspiring motive of his life, he avoided anything in the affairs of the state that went explicitly against the letter of the law (shar). Shah Jahan was even more orthodox and religious minded. He was, however, wise enough to maintain a balance between the claims of orthodoxy and the liberal traditions of his dynasty. He continued to constitute the Hindus in army as well as administration. As a modern Hindu historian has pointed out, the Hindus held a large number of high ranks in the Mughal army than the Indians did in the British army. ${ }^{2}$ An interesting strain of thought in Shah Jahan's reign is represented by Sheikh Muhibullah of Allahabad. He was a great admirer of Ibn Arabi and was himself highly respected as an exponent of wujudi mysticism. In certain directions he anticipated modern ideas. This is, for instance, his explanation of prophetic revelations through Gabriel.

\footnotetext{
${ }^{2}$. Sri Ram Sharma, Religious Policy of the Mughal Emperors
} 
"The Gabriel of Mohammad was a part of his person. Similarly the Gabriel of each prophet was in himself and through him (Gabriel) revelation was transmitted to the prophet. Hence, (it was that) the Gabriel of each prophet spoke to him in his own language." THE QADIRIS- MIAN MIR

Mujaddid Alf Sani had launched a furious attack on the wujudi mysticism, but the latter was far from succumbing to that attack. Its association with Sufism was too deep rooted to be severed at one stroke. Moreover the wujudi pantheism had such an inherent charm for the mystic mind that neither insistence on conformity with the shariat nor even the neo-mysticism of the Mujaddid could substantially weaken it. It is indeed attribute to the genius of Ibn Arabi as well as to the inherent spiritual and intellectual vitality of the wujudi idea that in every age it could claim to its fold great minds and great spirits. The period following the Mujaddid saw a resurgence of the wujudi mysticism under the auspices of Qadiri silsila. The credit for it goes to Sheikh Mina Mir of Lahore, who originally belonged to Sehwan in Sind. He was a great admirer of Ibn Arabi. He was very pious but his piety was of a mystic and not of the orthodox pattern. He was a recluse and remained engrossed in his meditations and penances. He would send his disciples to jungle for solitary meditation, which as an orthodox critic pointed out, prevented them from participating in congregational prayers. He came to see Jahangir at Agra. The latter was greatly impressed by him and speaks of him very highly in his memoirs. Shah Jahan also met him and was similarly impressed by him. Dara Shikoh was simply overwhelmed by his spiritual powers. The Sheikh won great fame and popularity during his lifetime and ranks among the great saints of the Mughal Age.

\section{MULLA SHAH- DARA SHIKOH}

Mian Mir's most notable disciple and his successor was Sheikh Mulla Shah Badakhshi Qadiri. He excelled even his preceptor in privations and penances. His ideas too were bolder than those of his master. Mulla Shah had among his admirers men of all faiths and persuasions. A Mughal Hindu noble, Wali Ram by name, gave up his wealth and rank and joined his circle. Wali's Persian verses-echo the themes of mystic love sung by Rumi and Jami. Shah Jahan held the Mulla in great esteem. Two of Shah Jahan's children, Dara Shikoh and Jahan Ara, became his disciples. Prince Dara Shikoh occupies a notable position in the history of Indo-Muslim mysticism. $\mathrm{He}$ was a profound student of comparative religion. Professor Habib describes him as "the only Indo-Muslim scholar to whom one can refer in the same breath as to Al Beruni." He in fact improved upon Al Beruni in as much as he made a diligent study of the Upnashads which had been inaccessible to $\mathrm{Al}$ Beruni. His strong pantheistic learning made him a great 
admirer of Vedantic philosophy and of Hindu Monists (muwahhidin). The prince, being the eldest son of the Emperor, occupied a position of preeminence in the country. Soon there recollected round him a number kindled spirits from among the Muslims as well as Hindus. The task of affecting a rapproactment between Islam and Hinduism was resumed in right earnest. Dara himself wrote a book entitled Majma-ul-Bahrain, The Confluence of the Two Oceans, in which he attempted a juxtaposition of sufic and yogic ideas. Both had to him the same spiritual and intellectual contents. Under Dara's inspirationand guidance a large number of Sanskrit works on religion and mysticism were translated into Persian. Dara's own work Majma-ulBahrain was translated into Sanskrit. Many high minded Hindus were thus inspired to a better appreciation of Muslim mysticism. Indeed it would be difficult to distinguish between the mystical writings of Chandra Bhan Brahman, Bhupat Rai Begham and Narain Bairagi on the one hand and those of Muslim sufis and other.

\section{THE WAR OF SUCCESSION}

Dara's wujudi mysticism was nothing short of heresy in the eyes of the orthodoxy. Some of his remarks, example, that the "Holy Quran is derived from the Upnashids," or "Thanks God that the conventional Islam vanished from my heart and (in its place) there appeared real paganism," caused an uproar and set the big guns of heterodoxy up against him. That the heir to the Mughal throne should have held such ideas was portentous. Dara's claim to the throne was, however, contested by his younger brother Aurangzeb. The war fought out between the two was not just a contest between ambitious rivals. It was something much more. The two princes represented two ideological camps, two distinctly marked out historical processes. The spiritual antecedents of the one were, Ibn Arabi, the wujudi mystics, the Bhakti saints, Akbar and Abul Fazl, and lastly Mian Mir and Mulla Shah; those of the other were Imam Ibn Taimiyya, the orthodox ulema of all ages Mujaddid Alf Sani, and Khwaja Mohammad (Aurangzeb is said to have been a disciple of Khwaja and in any case held him in great reverence). The orthodox camp was in fact fce to face with the situation as had confronted the Mujaddid. The question at issue was: should Islam stand as a missionary faith, sharply distinguished from other faiths, or should it be just one of the different paths to truth, all standing on a basis of equality and all equally justifiable? Were the bridges that were being built by the kindleled spirits from both sides to annihilate the distance and the difference between Islam and Hinduism to be continued and completed, or were they to be blown up? Was Islam to live on a basis of mutual recognition of equality, identity with other religious systems, or was it to stand in challenging antagonism to them. The issue of the contest was full of grave import for the future of 
Islam in Indo-Pakistan. Aurangzeb won the contest. This was the second historic step in the development of Muslim separatism.

\section{AURANGZEB'S RELIGIOUS POLICY}

The objective student of history must clearly distinguish between two things- the motives and objectives of Aurangzeb's policy on the one hand and on the other hand the factual results of his policy. Aurangzeb was actuated by a worthy motive: he aimed at shaping his policy in accordance with the shariat. It was immaterial to him if this caused inconvenience to anybody, to himself or to his Muslim subjects or to his Hindu subjects. Thus he lived a life of any privations and denied himself the comfort and luxury to which his imperial status entitled him. He lived a life of utter simplicity and rigorous piety. By his puritanical measures he tried, though rather vainly, to improve the moral tone of his Muslim and Hindu subjects. If he banned the celebration of Holi for reasons of social morality, he also banned the public observance of Muharram for similar reasons. If he abolished the celebration of Hindu festivals at the court, he also stopped the observance of the Persian Nauroz. If he re-imposed the jaziya as it was in accordance with the shariat. He abolished the other taxes as they were not sanctioned by the shariat. State protection was extended to hold temples as laid down by the shariat. Aurangzeb's motives are obvious. It stands to reason that if he was motivated by any hostility towards the Hindus, he would not have afforded financial relief to them by abolishing four scores of cesses, nor would have he encouraged the public observance of their religious ceremonies by removing taxes on them.

So much for his motives. But what were the practical results of his measures? Objectively speaking, he started with the best of motives but ended by antagonizing the Hindus. Let us take up one specific point, the reimposition of Jaziya and explore it thoroughly. Jiziya or the Zar-i-Dhimma was unquestionably a just and equitable tax as originally conceived. The Muslim government undertook the obligation (Dhimma) to protect the life, honor, property and religious liberty of non-Muslim subjects. Jiziya was thus the fees of the Muslim state for the service of protection. There have been cases when the Muslim government returned the money collected as jiziya if they felt unable to provide adequate protection to them. Be it remembered that the non-Muslims were exempted from the obligation of military service. It was the Muslims who had to bear the brunt of fighting. The entire adult male Muslim population was a body of potential fighters, any of whom could be at any time called upon to join active service. The jiziya was thus a boon to the non-Muslims. In the Ottoman Empire, the the non-Muslims preferred jiziya to the liability to serve in the army. However, in India by the sixteenth century jiziya had changed its import and significance. It had become associated with a sense of subjection and humiliation. Imam Ghazali 
(d. $1012 \mathrm{c}$.) in his own day had complained that jiziya was being realized by such cruel means that it ceased to be permissible or lawful. Qazi Mughithuddin of Ala-ud-din Khilji's reign (1296-1316) thus described the position of the Hindu tax prayer, "If the tax collector wants to spit into his mouth, he should open his mouth to receive the saliva." He observed that jiziya was meant to humiliate the Hindus and Ala-ud-din heartily agreed with his view. A body of ulema of Firuz Shah's reign (1351-1388) opined when consulted that the Brahmans should be made to pay the jiziya in a manner humiliating to them (vide, Afif, Tarikh-i-Firuz Shahi), Mujaddid Alf Sani, than whom it would be difficult to imagine a more authoritative exponent of the shariat, described that the jiziya was meant to humiliate and degrade the non-Muslims. It is immaterial wether the above cited persons interoperated the law correctly or incorrectly on this point. The important point is the meaning which the general body of Muslim theologians did actually attach to the term jiziya. The Hindu was thus made to feel that the poll tax was a hallmark of inferiority, subordination and degradation. On the question of jiziya thereof it would be unhistorical to take away the term from its contemporary associations and to appeal to its original meaning.

In regards to temples, Aurangzeb followed the principle, to quote his own words from the famous Benaras Farman: "It is laid down by the shar that the old temples are not to be pulled down but new temples are not to be set up." The same farman instructed the local officer to see that nobody tempered with the sanctity of the old temple at Benaras and that its Brahman keepers performed their duties undisturbed. As for the new temples, repeated orders were issued to demolish them. Repair of old temples was also forbidden.

Aurangzeb continued to employ the Hindus in fairly large number and in all ranks including the highest. The proportion of the Hindu employees however decreased in his reign. He also tried to break the Hindu monopoly of the Revenue Department for sound administrative reasons. A farman was thereof issued forbidding the employment of Hindus in the Revenue Department. The order was later on withdrawn and modified again for administrative reasons. There would have been many Hindus, however, who would have failed to see the administrative reasons behind these orders and whose sentiments would have been gravely injured. Here again, it is necessary to distinguish between motives and results.

A statesman should not take into consideration merely the inner soundness of his measures but should also give equal or even more consideration to the psychology, subjection and susceptibilities of his people. It is curious to conjure up if Aurangzeb ever pondered over the fact of Sultan Mohammad bin Tughlaq. Most of the projects of the Sultan were sound in principle but failed because of lack of adjustment with the sentiments of the people. There is a far cry from Mohammad bin Tughlaq to Aurangzeb in point of personality as well as policy. Yet there is this much common that both processed an inordinate confidence in the inner consistency and abstract 
justice of their measures and showed a woeful lack of appreciation of the sentiments of the people who were likely to be affected by them. 